\title{
Nitrogen top-dressing fertilization of maize cultivated in single and twin-row systems ${ }^{1}$
}

\author{
Lucas José Brame ${ }^{2}$, Anderson Prates Coelho ${ }^{2 *} \mathbb{D}$, Fábio Tiraboschi Leal ${ }^{2}$, Almir Salvador Neto ${ }^{2}$, \\ Fábio Luiz Checchio Mingotte ${ }^{2}$, Leandro Borges Lemos ${ }^{2}$
}

$10.1590 / 0034-737 X 202168010003$

\begin{abstract}
The aim of this study was to evaluate the effects of cropping systems (single and twin-rows) and $\mathrm{N}$ fertilizer rate in the second top-dressing on the agronomic performance and relative economic returns of maize. The experiment was conducted in a randomized block design, with subplots and three repetitions. The plots were composed of two cropping systems: single and twin-rows. The subplots consisted of six rate of $\mathrm{N}$ fertilizer, applied in the second top-dressing fertilization in the $\mathrm{V}_{8}$ phenological stage maize: $0,14,28,56$, and $70 \mathrm{~kg} \mathrm{ha}^{-1}$ of $\mathrm{N}$. The first application of $\mathrm{N}$ top-dressing fertilization $\left(140 \mathrm{~kg} \mathrm{ha}^{-1} \mathrm{~N}\right)$ was during the $\mathrm{V}_{4}$ phenological stage in all treatments. The cropping system of twin-rows provides a higher grain yield and relative economic return of maize. The agronomic efficiency of the twin-row cropping system decreases with increasing $\mathrm{N}$ rates, but remains higher than that obtained in the single-row system, independent of the $\mathrm{N}$ fertilizer top-dressing rate. The application of the second $\mathrm{N}$ top-dressing fertilization in the $\mathrm{V}_{8}$ phenological stage increases linearly with the grain yield and relative economic return of maize, independent of the cropping system.
\end{abstract}

Keywords: Zea mays L.; nitrogen rates; twin-rows; agronomic efficiency.

\section{INTRODUCTION}

In Brazil, maize is cultivated during two seasons, in a total area equivalent to 16.8 million ha (Conab, 2018). The first season, or summer crop, represents $31.3 \%$ of the annual area cultivated and the second crop, or off season crop, represents $68.7 \%$. However, the average yield of maize in Brazil is low $\left(5,400 \mathrm{~kg} \mathrm{ha}^{-1}\right)$, since in countries such as the United States the average crop yield exceeds $10,000 \mathrm{~kg} \mathrm{ha}^{-1}$, a value which is $100 \%$ higher than the Brazilian national average (USDA, 2018). In addition to increasing the yield, another important factor in agriculture is the increase in revenue, which can lead to greater profitability for farmers. For this, techniques with an easy agricultural management and good economic return, without any additional costs, must be prioritized for use.
Recently, studies have been conducted to evaluate the effects of different plant arrangements and spacings on maize yield, aiming to increase the grain yield without increasing the crop production costs (Lacerda et al., 2015). Among these studies, the use of maize sowing at reduced spacing $(0.45 \mathrm{~m}$ to $0.60 \mathrm{~m})$ and twin-rows $(0.45 \mathrm{~m} \times 0.90 \mathrm{~m})$ can be highlighted. These types of spatial plant arrangements provide a greater resource utilization, especially for solar radiation and nitrogen use, promoting a greater growth and yield of maize, relative to the cropping system with larger spacings between rows (0.80$0.90 \mathrm{~m}$ ) (Robles et al., 2012). However, little is known about the effects of these new production systems on the agronomic attributes of maize.

The twin-row cropping system is a system in which the variation of spacing between plants at the time of

\footnotetext{
Submitted on July $17^{\text {th }}, 2020$ and accepted on October $10^{\text {th }}, 2020$.

${ }^{1}$ This work is part of the scientific initiation work of the first author.

${ }^{2}$ Universidade Estadual Paulista (Unesp), Faculdade de Ciências Agrárias e Veterinárias, Jaboticabal, São Paulo, Brasil. brameagr@gmail.com; anderson_100ssp@hotmail.com; lealft@bol.com.br; almirasn_salvador@hotmail.com; flcmingotte@gmail.com; leandro.lemos@unesp.br

*Corresponding Author: anderson_100ssp@hotmail.com
} 
sowing interferes less in the final yield than when maize is cultivated in single-rows (Robles et al., 2012). In Brazil, little is known about this cropping system, however, in the USA there are commercial plantations that use this system, which results increases in the grain yield compared to conventional sowing (Thomas \& Mahanna, 2013).

In conventional maize systems, with row spacings between 0.80 to $0.90 \mathrm{~m}$, recommended nitrogen fertilization has a maximum rate of $140 \mathrm{~kg} \mathrm{ha}^{-1}$ and can be divided three times until flowering (Cantarella et al., 1997). However, for the new maize cropping systems that use reduced singlerow spacings and twin-rows, this management can be changed to maximize the grain yield and economic return, since in these systems the competition between plants is different and, in many cases, there is a higher nutritional requirement to obtain maximum grain yields (Lana et al., 2014; Yan et al., 2017).

The aim of this study was to evaluate the effects of cropping systems (single and twin-rows) and $\mathrm{N}$ fertilizer rate in the second top-dressing, on the agronomic performance and relative economic returns for maize.

\section{MATERIALS AND METHODS}

The experiment was conducted at the School of Agricultural and Veterinarian Sciences, São Paulo State University (Unesp), Jaboticabal, SP, located at $21^{\circ} 13^{\prime} 42.11^{\prime \prime} \mathrm{S}$ and $48^{\circ} 16^{\prime} 52.12^{\prime \prime} \mathrm{W}$, with an average altitude of $570 \mathrm{~m}$. The climate, according to Koppen's classification, is Aw, tropical humid with hot and humid summers and cold and dry winters (Alvares et al., 2013). During the experimental period, for the summer crop of $2015 / 16$, the average maximum and minimum temperatures were $30.9^{\circ} \mathrm{C}$ and $20.1^{\circ} \mathrm{C}$, respectively, and the total precipitation was $1335.8 \mathrm{~mm}$ (Figure 1).

The soil is classified as Red Oxisol, with a clayey texture (Embrapa, 2013). Soil chemical analysis, for fertility purposes, was performed prior to the installation of maize

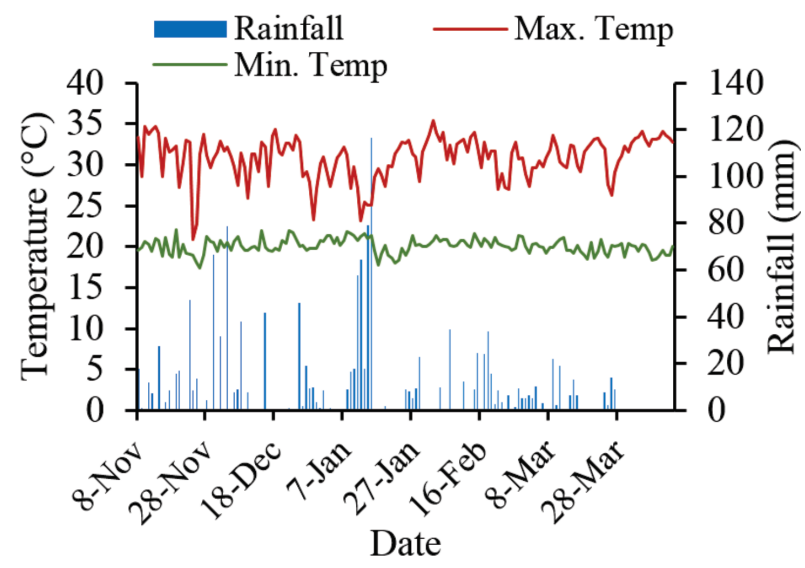

Figure 1: Maximum and minimum temperatures and daily precipitation during the experimental period. in the 0.00-0.20 m depth layer (Raij et al., 2001). The values of the chemical attributes were $\mathrm{pH}\left(\mathrm{CaCl}_{2}\right)=5.8$, O.M. $=26$ $\mathrm{g} \mathrm{kg}^{-1}, \mathrm{P}($ resin $)=37 \mathrm{mg} \mathrm{dm}^{-3}, \mathrm{H}+\mathrm{Al}=29 \mathrm{mmol}_{\mathrm{c}} \mathrm{dm}^{-3}, \mathrm{~K}=$ $4.1 \mathrm{mmol}_{\mathrm{c}} \mathrm{dm}^{-3}, \mathrm{Ca}=36 \mathrm{mmol}_{\mathrm{c}} \mathrm{dm}^{-3}, \mathrm{Mg}=14 \mathrm{mmol}_{\mathrm{c}} \mathrm{dm}^{-3}$, $\mathrm{CEC}=83.1 \mathrm{mmol}_{\mathrm{c}} \mathrm{dm}^{-3}$, and $\mathrm{BS}=65 \%$.

The area was cultivated in a conventional tillage system. In the previous agricultural year (2014/15), maize was cultivated in the summer season and the field was left fallow after the cereal harvest. In the present study, the hybrid used was P283OH (Dupont Pioneer), which has a super early cycle and high yield potential. The plant population used for all treatments was $66,000 \mathrm{ha}^{-1}$ plants.

The maize sowing was carried out on November 8, 2015, using an Exacta Air fertilizer model (JM2670), brand Jumil, with a pneumatic seed distribution system. The maize fertilization was performed with $375 \mathrm{~kg} \mathrm{ha}^{-1}$ of the formulated $08-28-16$, providing 30,105 , and $60 \mathrm{~kg} \mathrm{ha}^{-1}$ of $\mathrm{N}, \mathrm{P}_{2} \mathrm{O}_{5}$, and $\mathrm{K}_{2} \mathrm{O}$, respectively (Cantarella et al., 1997).

The experimental design was a randomized complete block design with three repetitions. The plots were composed of two cropping systems (CS): single and twinrows. In the single-row system, the row spacing was 0.45 $\mathrm{m}$, whilst in the twin-row system it was $0.45 \times 0.90 \mathrm{~m}$. The subplots were composed of six $\mathrm{N}$ fertilizer rate, applied in in the second top-dressing during the $\mathrm{V}_{8}$ phenological stage (eight fully developed leaves) in maize (12/21/2015): $0,14,28,56$, and $70 \mathrm{~kg} \mathrm{ha}^{-1}$ of $\mathrm{N}$. The first application of $\mathrm{N}$ in the top-dressing (rate of $140 \mathrm{~kg} \mathrm{ha}^{-1}$ of N) was carried out during the $\mathrm{V}_{4}$ phenological stage (four fully developed leaves) in all treatments (12/08/2015) (Cantarella et al., 1997). The total rates in the top-dressing were $140+0,140$ $+14,140+28,140+56$, and $140+70 \mathrm{~kg} \mathrm{ha}^{-1}$ of $\mathrm{N}$. The source of $\mathrm{N}$ used was conventional urea. Each subplot was formed by eight rows of maize in the single-row system and by six rows in the twin-row system, all of which were $10 \mathrm{~m}$ in length. Only the 3 central rows were considered for evaluation, whilst all others were ignored to avoid the effects of the border.

Together with the $\mathrm{N}, 60 \mathrm{~kg} \mathrm{ha}^{-1}$ of $\mathrm{K}_{2} \mathrm{O}$ was applied in the first top-dressing fertilization, using potassium chloride as the source. The fertilizer distribution was in continuous fillet, $0.10 \mathrm{~m}$ from the plant rows.

The herbicides tembotrione (100.8 $\mathrm{g} \mathrm{ha}^{-1}$ of i.a.) and atrazine ( $3 \mathrm{~kg} \mathrm{ha}^{-1}$ of i.a.) were applied for weed control on $12 / 04 / 2015$, when the crop was in the $V_{3}$ stage. For disease control, a fungicide composed of pyraclostrobin + metconazole (126 $\mathrm{g} \mathrm{ha}^{-1}$ of i.a.) was applied on 12/22/2015, when the crop was in the $\mathrm{V}_{8}$ stage. For the control of caterpillars, the application of the insecticides lambdacyhalothrin + chlorantraniliprole (7.5 and $15 \mathrm{~g} \mathrm{ha}^{-1}$ of i.a., respectively) and teflubenzuron ( $15 \mathrm{~g} \mathrm{ha}^{-1}$ of i.a) was carried out on 12/22/2015. 
For the determination of the leaf $\mathrm{N}$ contents, ten leaves were collected per subplot during the $\mathrm{R}_{1}$ phenological stage (female flowering). The leaves located below and opposite the main ear were collected, removing the middle third and central vein for analysis (Coelho et al., 2002). The material was washed in running water, $1 \%$ neutral aqueous detergent solution, and distilled water and then oven dried, with forced air circulation at a temperature of $65^{\circ} \mathrm{C}$, until a constant mass was reached. The dried samples were milled in a Wiley-type mill and subjected to sulfur digestion to determine the $\mathrm{N}$ contents (Bataglia et al., 1983).

During the stage of physiological maturity of maize $\left(R_{6}\right)$, the final height of the plants $(m)$, height of insertion of the ear $(\mathrm{m})$, stem diameter $(\mathrm{mm})$, number of rows and grains per ear, mass of 1000 grains, and grain yield (kg ha $\left.{ }^{1}\right)$ were evaluated. The height of the plant was the distance from the soil level to the insertion of the last leaf. The height of insertion of the main ear was measured between the collar of the plant and the insertion of the main ear. The stem diameter was measured using a pachymeter, at a height of $10 \mathrm{~cm}$ from the ground. All these attributes were determined in 10 plants per subplot. For the determination of the number of rows and grains per ear, five ears from each subplot were removed. The mass of 1000 grains was determined by random sampling and weighing of four samples of 300 grains, representing the useful area of each subplot, with correction of the values to $0.13 \mathrm{~kg} \mathrm{~kg}^{-1}$. Grain yield was estimated by hand harvesting the ears of the useful area in each subplot, before they were mechanically trodden to determine the grain yield, correcting the water content to $0.13 \mathrm{~kg} \mathrm{~kg}^{-1}$.

The agronomic efficiency (AE) was calculated according to Fageria \& Baligar (2005), using equation 1:

$\mathrm{AE}=\frac{\mathrm{GYcf}-\mathrm{GYsf}}{\mathrm{QNcf}-\mathrm{QNsf}}$

In which,

AE: agronomic efficiency $\left(\mathrm{kg} \mathrm{kg}^{-1}\right)$; GYcf: grain yield ( $\mathrm{kg}$ $\mathrm{ha}^{-1}$ ) with fertilization in the second top-dressing; GYsf: grain yield $\left(\mathrm{kg} \mathrm{ha}^{-1}\right)$ without fertilization in the second top-dressing; QNcf: amount of $\mathrm{N}$ applied $\left(\mathrm{kg} \mathrm{ha}^{-1}\right)$ in the second top-dressing; and QNsf: no fertilization in the second top-dressing.

The relative economic return (RER: $\mathrm{R} \$ \mathrm{ha}^{-1}$ ) was calculated using equation 2 :

$\mathrm{RER}=($ Psc $x \mathrm{GY})-(\mathrm{PN} \times \mathrm{R})$

In which,

RER: relative economic return $\left(\mathrm{R} \$ \mathrm{ha}^{-1}\right)$; Psc: price of a 60 $\mathrm{kg}$ bag of maize on the date of $05 / 03 / 2018\left(\mathrm{R} \$ 40.03 \mathrm{bag}^{-1}\right)$; GY: grain yield (bags ha-1); PN: price of a $\mathrm{kg}$ of $\mathrm{N}$ of urea $\left(\mathrm{R} \$ 2.70 \mathrm{~kg}^{-1}\right)$; and $\mathrm{R}$ : applied $\mathrm{N}$ rate $\left(\mathrm{kg} \mathrm{ha}^{-1}\right)$.
The data were submitted to an analysis of variance by the $\mathrm{F}$ test $(\mathrm{p}<0.05)$ and means were compared by the Tukey test $(\mathrm{p}<0.05)$ with the software SISVAR $®$ (Ferreira, 2011). The values for the nitrogen rates in the topdressing and interaction between the cropping systems and $\mathrm{N}$ rates were also compared by means of polynomial regression.

\section{RESULTS AND DISCUSSION}

The effects of cropping systems (CS) and $\mathrm{N}$ fertilizer rate in the top-dressing $(\mathrm{R})$, on the agronomic attributes of maize were evaluated (Table 1). The CS did affect the height of the plants, whereas for $\mathrm{R}$ there was a significant effect for all attributes $(\mathrm{p}<0.05)$. The interaction between CS and $\mathrm{R}$ was only significant for the stem diameter (Table 1).

When cultivated in twin-rows, maize plants presented a higher leaf $\mathrm{N}$ content and stem diameter, with a mean of $2 \%$ and $10 \%$ higher, respectively, and a lower ear insertion height, with a mean of $5 \%$ lower. Regarding the greatest difference in the attributes, this occurred in the stem diameter. This is an important attribute for maize, since the lodging of the plants decreases with increasing stem diameter (Uribe et al., 2017), and the positive effect that cultivation in twin-rows had for this characteristic can be highlighted (Bettio et al., 2017).

For factor R, it can be seen that all attribute means increased with the elevation of $\mathrm{N}$ rates in top-dressing (Figure 2). For each cropping system, it was possible to model the behavior of the attributes as a function of the $\mathrm{N}$ fertilizer rate in top-dressing $(\mathrm{p}<0.05)$, except for the plant height in the single-row cropping system.

For the leaf $\mathrm{N}$ contents, the twin-row system presented higher increases, due to the increase in $\mathrm{N}$ rates, than that for the single-row cropping system (Figure 2A), since in the single-row $\mathrm{CS}$ the leaf $\mathrm{N}$ contents did not differ between the rates. For the $\mathrm{CS}$ with twin-rows, there was a significant increase $(p<0.05)$ in the leaf $N$ content. Through the regression analysis, it was evident that the highest leaf $\mathrm{N}$ contents were obtained with rates of $\mathrm{N}$ fertilizer of $242 \mathrm{~kg}$ $\mathrm{ha}^{-1}$ and $101 \mathrm{~kg} \mathrm{ha}^{-1}$ for the single and twin-row cropping systems, respectively.

By plotting the CS versus $\mathrm{R}$ interaction for the stem diameter (Figure 2D), it was observed that when maize did not receive the second top-dressing fertilization, the values were the same among the cropping systems, while from 14 $\mathrm{kg} \mathrm{ha}^{-1}$ in the second top-dressing fertilizer, the stem diameter was higher for the CS of twin-rows. According to the regression analysis, the maximum stem diameter for a CS with twin-rows ( $29 \mathrm{~mm}$ ) was obtained with the $\mathrm{N}$ rate in topdressing fertilization of $202,5 \mathrm{~kg} \mathrm{ha}^{-1}$.

For the maize grain yield and yield components, the CS and R effected all attributes ( $p<0.05)$, except for the number of rows ear (Table 2). The CS of twin-rows 
presented a higher number of grains per row, grain per ear, mass of 1000 grains, and grain yield. For the latter, CS with twin-rows presented a mean $12 \%$ higher than CS with single-rows, equivalent to $870 \mathrm{~kg} \mathrm{ha}^{-1}$.

The number of grains per row, number of grains per ear, and grain yield presented a linear increase with the increase of $\mathrm{N}$ rates in top-dressing fertilization (Figure 3 ). The mass of 1000 grains presented a quadratic increase with the elevation of $\mathrm{N}$ fertilizer rate, for the two cropping systems (CS), with maximum values obtained with $\mathrm{N}$ rates of $224 \mathrm{~kg} \mathrm{ha}^{-1}$ and $215 \mathrm{~kg} \mathrm{ha}^{-1}$ for the cropping system of single and twin-rows, respectively. It can be observed for the grain yield that, with the elevation of $\mathrm{N}$ fertilizer rate in top-dressing fertilization, the differences between CS decrease. This can be confirmed by the average letters of the treatments, since only treatments receiving a $\mathrm{N}$ fertilizer rate of $182 \mathrm{~kg} \mathrm{ha}^{-1}$ in top-dressing fertilization presented statistically equal means $(\mathrm{p}<0.05)$ and below this rate the $\mathrm{CS}$ of twin-rows showed a grain yield higher than that of the CS of single-rows.

The agronomic efficiency (AE) of maize was maximal for the CS of twin-rows with the $\mathrm{N}$ rate of $154 \mathrm{~kg} \mathrm{ha}^{-1}$ in top-

Table 1: Nitrogen content, plant height, ear insertion height, and stem diameter as a function of the cropping systems and $\mathrm{N}$ fertilizer rate applied in maize top-dressing

\begin{tabular}{|c|c|c|c|c|}
\hline \multirow{2}{*}{ Treatments } & Leaf $N$ content & Plant height & Ear insertion & Stem diameter \\
\hline & $\mathrm{g} \mathrm{kg}^{-1}$ & $\mathbf{m}$ & $\mathbf{m}$ & $\mathbf{m m}$ \\
\hline Single-rows & $30.99 \mathrm{~b}$ & $2.27 \mathrm{a}$ & $1.12 \mathrm{a}$ & $25.22 \mathrm{~b}$ \\
\hline Twin-rows & $31.58 \mathrm{a}$ & $2.21 \mathrm{a}$ & $1.06 \mathrm{~b}$ & $27.74 \mathrm{a}$ \\
\hline $\mathrm{CV}(\%)$ & 0.58 & 3.47 & 1.61 & 1.26 \\
\hline \multicolumn{5}{|l|}{ F test } \\
\hline $\mathrm{CS}$ & $93,44 *$ & $6.53^{\mathrm{ns}}$ & $89.15^{*}$ & $511.43 * *$ \\
\hline $\mathrm{R}$ & $3,69 *$ & $3.49 *$ & $3.94 *$ & $12.56 * *$ \\
\hline $\mathrm{CS} \times \mathrm{R}$ & $0,32^{\mathrm{ns}}$ & $0.83^{\mathrm{ns}}$ & $0.57^{\mathrm{ns}}$ & $4.53 * *$ \\
\hline
\end{tabular}

$\mathrm{CS}$ - cropping system; $\mathrm{R}$ - rates of $\mathrm{N}$; and $\mathrm{CV}$ - coefficient of variation. *Significant at $5 \%$ probability; **Significant at $1 \%$ probability; and ns - not significant.
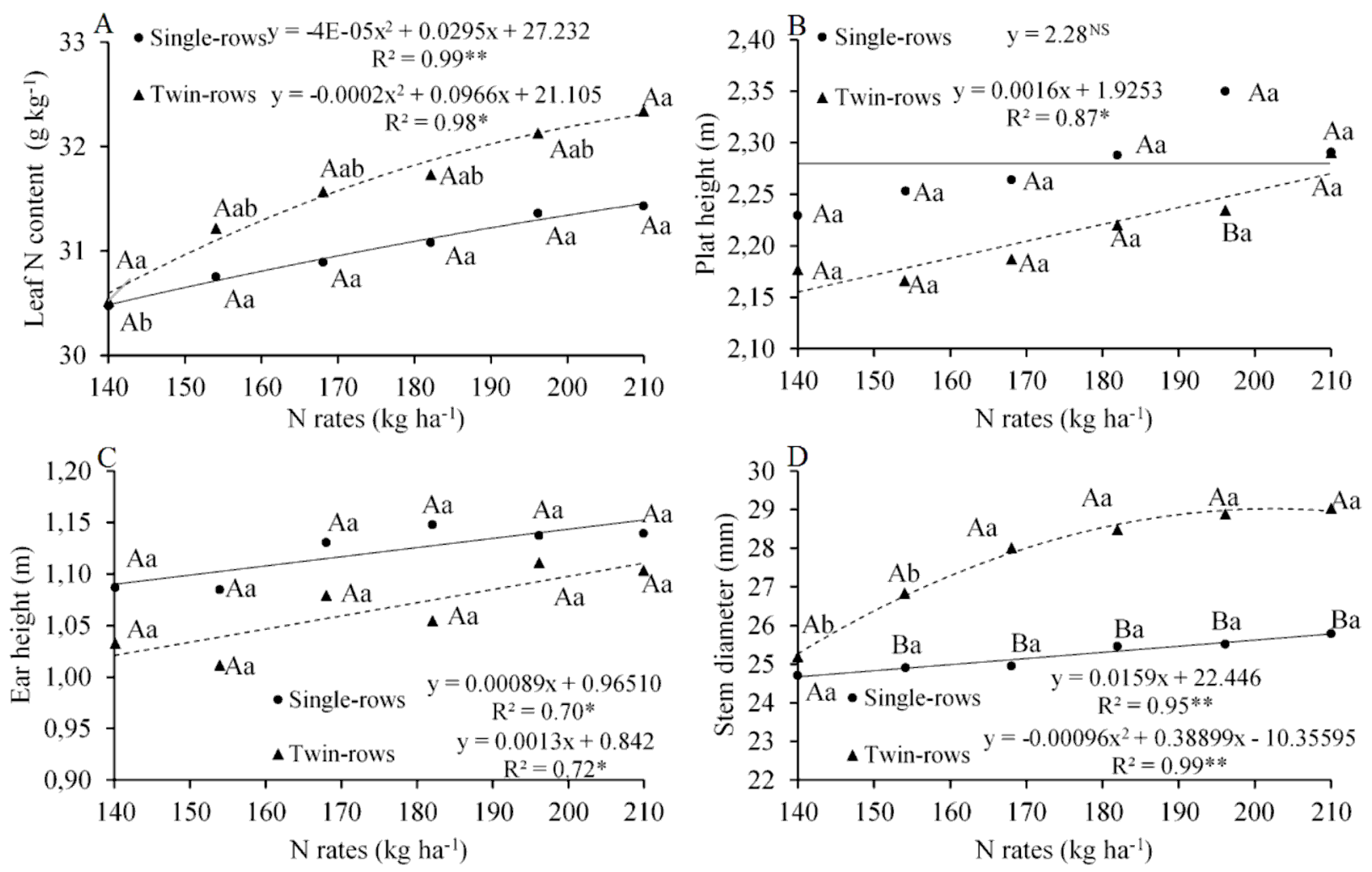

Figure 2: Evolution of the interactions between cropping systems and $\mathrm{N}$ fertilizer rate for the leaf nitrogen content (A), plant height (B), ear insertion height (C), and stem diameter of maize (D). Lower case letters compare rates within cropping systems and upper case compare cropping systems within rates. *Significant at $5 \%$ probability; **Significant at $1 \%$ probability; and ns - not significant. 
Table 2: Number of rows and grains per row, number of grains per ear, mass of 1000 grains, and grain yield, according to the cropping system and $\mathrm{N}$ fertilizer rate applied in the top-dressing for maize

\begin{tabular}{|c|c|c|c|c|c|}
\hline \multirow{2}{*}{ Treatments } & Rows per ear & Grains per rows & Grains per ear & \multirow{2}{*}{$\frac{\text { Mass of } 1000 \text { grains }}{\mathrm{g}}$} & \multirow{2}{*}{$\begin{array}{c}\text { Grain yield } \\
\mathrm{kg} \mathrm{ha}^{-1}\end{array}$} \\
\hline & \multicolumn{3}{|c|}{ Number } & & \\
\hline Single-rows & $18.46 \mathrm{a}$ & $33.12 \mathrm{~b}$ & $611.73 \mathrm{~b}$ & $323.91 \mathrm{~b}$ & $7,436 \mathrm{~b}$ \\
\hline Twin-rows & $18.55 \mathrm{a}$ & $36.18 \mathrm{a}$ & $671.61 \mathrm{a}$ & $324.11 \mathrm{a}$ & $8,304 \mathrm{a}$ \\
\hline $\mathrm{CV}(\%)$ & 1.77 & 3.28 & 1.61 & 0.03 & 6.67 \\
\hline \multicolumn{6}{|l|}{$\bar{F}$ test } \\
\hline $\mathrm{CS}$ & $0.66^{\mathrm{ns}}$ & $65.61 *$ & $300.60 * *$ & $49.00 *$ & $24.64 *$ \\
\hline $\mathrm{R}$ & $1.77^{\mathrm{ns}}$ & $18.51 * *$ & $17.23 * *$ & $98.00 * *$ & $10.22 * *$ \\
\hline $\mathrm{CS} \times \mathrm{R}$ & $0.72^{\mathrm{ns}}$ & $0.89^{\mathrm{ns}}$ & $0.73^{\mathrm{ns}}$ & $0.08^{\mathrm{ns}}$ & $1.27^{\mathrm{ns}}$ \\
\hline
\end{tabular}

CS - cropping system; $\mathrm{R}$ - rates of $\mathrm{N}$; and $\mathrm{CV}$ - coefficient of variation. *Significant at $5 \%$ probability; **Significant at $1 \%$ probability; and ns - not significant.
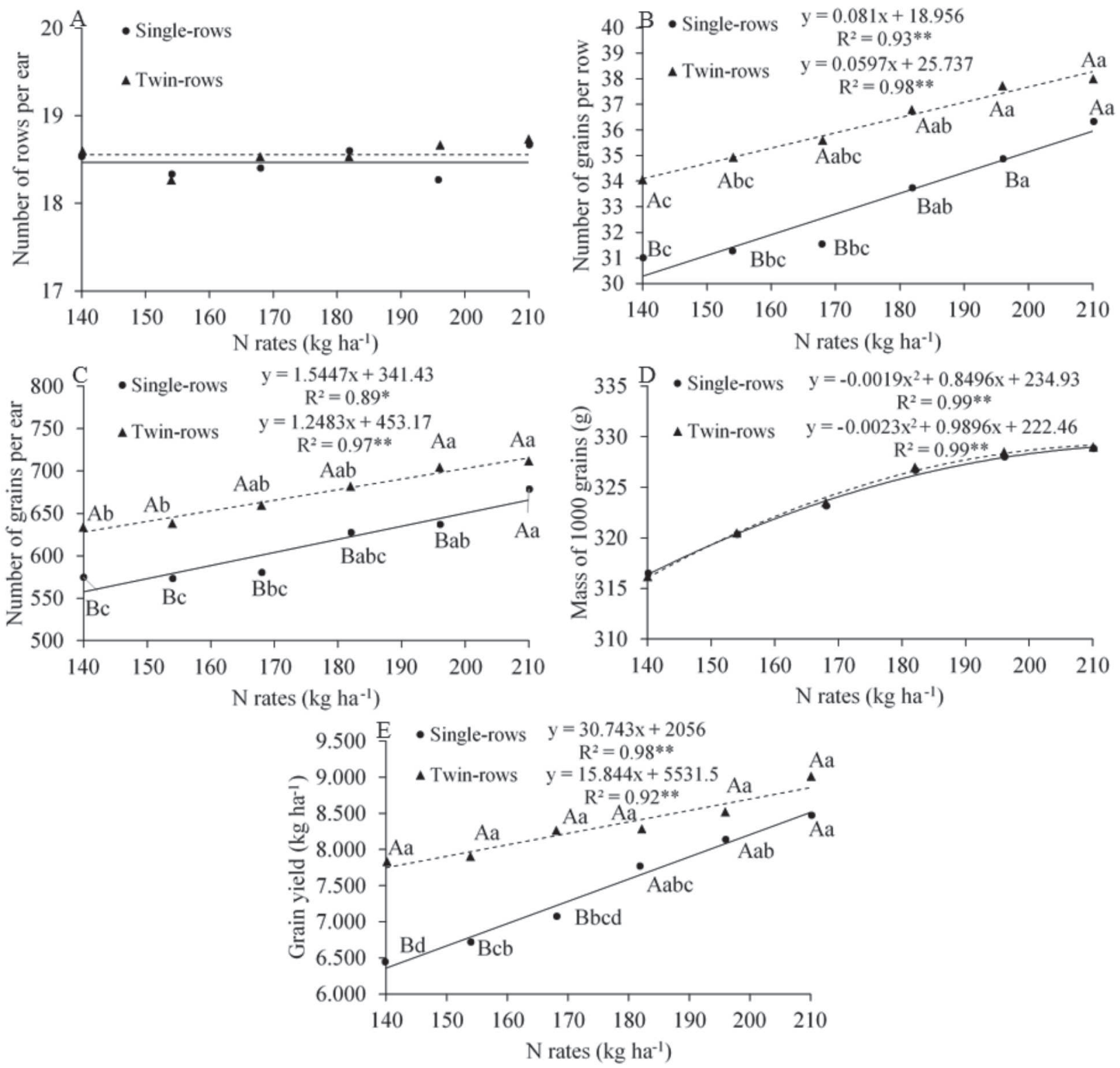

Figure 3: Evolution of the interactions between the cropping systems and $\mathrm{N}$ fertilizer rate for the number of rows per ear (A), number of grains per row (B), number of grains per ear (C), mass of 1000 grains (D), and grain yield of maize (E). Lower case letters compare rates within cropping systems and upper case letters compare cropping systems within rates. *Significant at 5\% probability; $* *$ Significant at $1 \%$ probability; and ns - not significant. 
dressing fertilization (Figure 4A). For this CS, the elevation of the $\mathrm{N}$ rate in top-dressing fertilization decreased the $\mathrm{AE}$ up to the minimum value of $35.36 \mathrm{~kg} \mathrm{~kg}^{-1}$. Within the range of $\mathrm{N}$ rates in top-dressing fertilization (140 to $210 \mathrm{~kg} \mathrm{ha}^{-1}$ ), in which the regressions were adjusted, the minimum value for the $\mathrm{AE}$ ( $35.36 \mathrm{~kg} \mathrm{~kg}^{-1}$ for $\mathrm{R}=199 \mathrm{~kg} \mathrm{ha}^{-1}$ ) for the $\mathrm{CS}$ of twin-rows was higher than the maximum value for the $\mathrm{AE}$ in a single-row cropping system $\left(31.32 \mathrm{~kg} \mathrm{~kg}^{-1}\right.$ for $\mathrm{R}=210 \mathrm{~kg}$ $\left.\mathrm{ha}^{-1}\right)$. This indicates that the CS of twin-rows in maize presents a higher $\mathrm{AE}$ than that of single-rows. Only from the $\mathrm{N}$ fertilizer rate of $182 \mathrm{~kg} \mathrm{ha}^{-1}$ for a single-row CS, was the AE statistically equal to that of the CS of twin-rows, confirming the best use of $\mathrm{N}$ in the twin-row system.

The relative economic return (RER) was higher for the CS of twin-rows, until the $\mathrm{N}$ rate of $168 \mathrm{~kg} \mathrm{ha}^{-1}$ in topdressing fertilization $(p<0.05)$. The greatest difference between the CS occurred when the nitrogen fertilization was not performed in the second top-dressing, with the RER being 24\% higher for CS in twin-rows.

It was observed in the present study that the agronomic performance of maize is superior in the CS of twin-rows. The higher $\mathrm{N}$ content in the leaves and greater stem diameter in this CS are indicative to the competition for the environment resources being lower in this system, since these two components are affected negatively by intraspecific competition (Robles et al., 2012; Miotto Júnior, 2014). This is because the CS of twin-rows provides a 'border' effect within the crop, since the spacing between the twin-rows is twice the spacing between single-rows, providing a greater interception of the radiation (Robles et al., 2012), and increasing the leaf area index and radiation use efficiency of the crop (Balkcom et al., 2011). In addition, it can be observed that in this CS the variation in the plant spacing at the time of sowing interferes less in the final grain yield than when maize is cultivated in singlerows (Robles et al., 2012).

Among the yield components, only the number of rows per ear was not higher for the CS of twin-rows (Table 2). This is because this is a feature with greater genotypic interference compared to management influence, such as the number of grains per row/ear and mass of 1,000 grains (Farinelli \& Lemos, 2012). However, the higher values of these last three components for the twin-row CS are associated with the higher leaf $\mathrm{N}$ contents for this CS, due to the greater availability of this nutrient to be translocated to the reproductive organs (Brown et al., 2014).

In some studies, maize sowing in twin-rows did not significantly increase the crop grain yield (Bruns et al., 2012; Robles et al., 2012; Novacek et al., 2013). However, the spacings between twin and single-rows evaluated by these authors, with a distance of $0.20 \mathrm{~m}$ between singlerows and up to $0.75 \mathrm{~m}$ between twin-rows, are smaller than those studied in the present study. This indicates that smaller spacings for CS with twin-rows may provide greater competition for the environment than larger spacings, such as the ones evaluated in the present experiment, where the distance between single and twin-rows was $0.45 \mathrm{~m}$ and 0.90 $\mathrm{m}$, respectively. In addition, considering the Brazilian conditions, the spacing used in the present study presents more advantages, as most of the existing planters in the country have rows spaced by $0.45 \mathrm{~m}$, and do not require additional adjustments for maize or other crop grains, such as soybeans and common beans.

Some studies indicate that the optimum population density for maize crop in twin-rows is higher than that cultivated in single-rows (Bruns et al., 2012; Balem, 2013; Novacek et al., 2013). However, in the present study the maize population was the same for the CSs, showing the best spatial distribution of the plants in the area in the CS of twin-rows, with an aim to reduce the intraspecific competition caused by the environment. All of this leads to the higher agronomic efficiency (AE) of the maize crop in this CS, as can be seen in Figure 4A. Up to the $\mathrm{N}$ rate of $168 \mathrm{~kg} \mathrm{ha}^{-1}$ in top-dressing fertilizer, the AE was greater than $60 \mathrm{~kg} \mathrm{~kg}^{-1}$ for the CS of twin-rows. This value is double the AE observed in the present study and in other experiments with CS of single-rows (Vanlauwe et al., 2011; Farinelli \& Lemos, 2012), confirming a greater efficiency in the grain yield can be achieved by the amount of $\mathrm{N}$ applied in this CS.

For $\mathrm{N}$ fertilization, the increases in the grain yield, $\mathrm{AE}$, and RER were more rapid for the CS of single-rows with an increasing $\mathrm{N}$ rate, since the largest angular coefficient of the equations was adjusted for this cropping system (Figures $3 \mathrm{E}$ and 4). The values for the CS of twin-rows were higher, regardless of the rates, because the constant of the equation (parameter b) was higher for this CS. As the competition between plants in the CS of single-rows is higher (Robles et al., 2012), there is a need for higher $\mathrm{N}$ rates to reach parameters with similar levels as those of the twin-row CS.

It can be seen that the use of a CS with single-rows and reduced spacing, requires higher rates of $\mathrm{N}$ in the top-dressing for the maximum grain yield, than the same system with traditional spacings $(0.80-0.90 \mathrm{~m})$ (Lana et al., 2014). This is even more pronounced when the crops have a higher density, which is one of the characteristics of a CS of maize with reduced row spacings (Yan et al., 2017). Therefore, to avoid using high rates of $\mathrm{N}$ in one application, and to reduce nutrient losses due to volatilization and leaching, the second top-dressing fertilization in a CS with single-rows and reduced spacing may become an essential practice in this new production system, due to the increases of grain yield and RER observed in this study (Figures 3E and 4B). This confirms that maize positively responds to the application of $\mathrm{N}$ in two top-dressing 

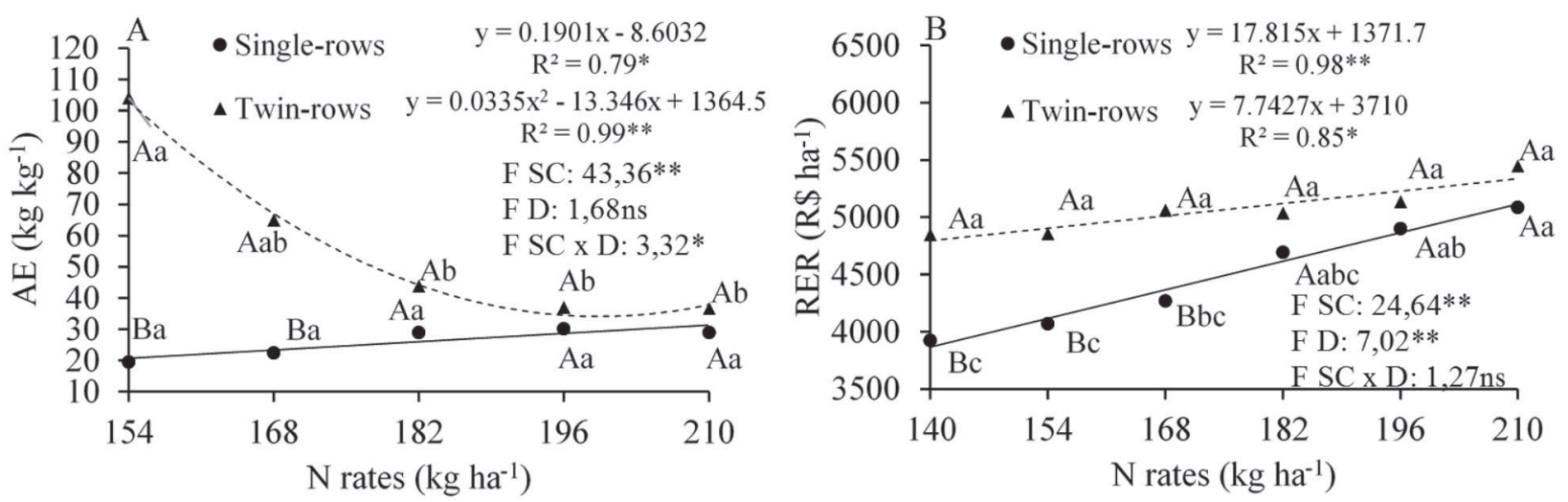

Figure 4: Agronomic efficiency (AE) and relative economic return (RER) (B) as a function of the cropping system and top-dressing nitrogen rates in maize. Lower case letters compare rates within cropping systems and upper case letters compare cropping systems within rates. *Significant at $5 \%$ probability; $* *$ Significant at $1 \%$ probability; and ns - not significant.

fertilizations at rates higher than $140 \mathrm{~kg} \mathrm{ha}^{-1}$ of $\mathrm{N}$, which is the maximum recommended rate for the crop (Cantarella $e t$ al., 1997; Amado et al., 2017).

It was also observed that only with the changes to the spatial distribution of the plants, did the maize grain yield increase by up to $22 \%$ in the CS of twin-rows (Figure 3E), guaranteeing a higher income to the farmers without affecting the production costs of the crop.

\section{CONCLUSIONS}

The agronomic performance and relative economic return of maize in a twin-row cropping system are superior to those obtained in the single-row cropping system.

The $\mathrm{N}$ rate in top-dressing fertilization increases linearly with the grain yield and relative economic return of maize, independently of the cropping system. The second nitrogen top-dressing fertilization for maize is recommended, especially in the single-row cropping system.

\section{ACKNOWLEDGEMENTS, FINANCIAL SUPPORT AND FULL DISCLOSURE}

The author thank to the Conselho Nacional de Desenvolvimento Científico e Tecnológico (CNPq) for granting the scholarship to the second author and to Coordenação de Aperfeiçoamento de Pessoal de Nível Superior (CAPES) for granting the scholarship to the third author. The authors declare than there is not conflict of interest.

\section{REFERENCES}

Alvares CA, Stape JL, Sentelhas PC, Moraes G, Leonardo J \& Sparovek G (2013) Köppen's climate classification map for Brazil. Meteorologische Zeitschrift, 22:711-728.

Amado TJC, Villalba EOH, Bortolotto RP, Nora DD, Bragagnolo J \& León EAB (2017) Yield and nutritional efficiency of corn in response to rates and splits of nitrogen fertilization. Revista Ceres, 64:351-359.
Balem Z (2013) Avaliação de espaçamento convencional e linhas gêmeas sob densidade populacional para cultura do milho. Dissertação de Mestrado. Universidade Tecnológica Federal do Paraná, Pato Branco. 76p.

Balkcom KS, Satterwhite JL, Arriaga FJ, Price AJ \& Van Santen E (2011) Conventional and glyphosate-resistant maize yields across plant densities in single-and twin-row configurations. Field Crops Research, 120:330-337.

Bataglia OC, Furlani AMC, Teixeira JPF, Furlani PR \& Gallo JR (1983) Métodos de análise química de plantas. Campinas, Instituto Agronômico. 48p. (Boletim técnico, 78).

Bettio CS, Ganascini D, Wunsh CA, Renosto L, Maggi MF \& Gurgacz F (2017) Produtividade do milho (Zea mays L.) com diferentes arranjos populacionais em linhas simples e duplas. Acta Iguazu, 6:44-51.

Brown KH, Bach EM, Drijber RA, Hofmockel KS, Jeske ES, Sawyer JE \& Castellano MJ (2014) A long term nitrogen fertilizer gradient has little effect on soil organic matter in a high intensity maize production system. Global Change Biology, 20:13391350 .

Bruns HA, Ebelhar MW \& Abbas HK (2012) Comparing singlerow and twin-row corn production in the mid-south. Crop Management, 11:1-8.

Cantarella H, Raij BV \& Camargo CEO (1997) Cereais. In: Raij BV, Cantarella H, Quaggio JA \& Furlani AMC. (Ed.) Recomendação de adubação e calagem para o Estado de São Paulo. Campinas, Instituto Agronômico. p.43-71.

Coelho AM, França GE, Pitta GVE, Alves VMC \& Hernani LC (2002) Cultivo do milho nutrição e adubação. Sete Lagoas, Embrapa. 12p. (Comunicado técnico, 44).

Conab - Companhia nacional de abastecimento (2018) Acompanhamento da safra brasileira: grãos. Segundo Levantamento, 6(2), safra-2018/19, n.2, segundo levantamento, novembro. Available at: 〈https://www.conab.gov.br/info-agro/safras/graos> Accessed on: December $11^{\text {th }}, 2018$.

Embrapa - Empresa Brasileira de Pesquisa Agropecuária (2013) Sistema brasileiro de classificação de solos. $3^{\text {rd }}$ ed. Brasília, Embrapa. 412p.

Fageria NK \& Baligar VC (2005) Enhancing nitrogen use efficiency in crop plants. Advances in Agronomy, 88:97-185.

Farinelli R \& Lemos LB (2012) Topdressing nitrogen in maize crop under consolidated conventional and no-tillage systems. Pesquisa Agropecuária Tropical, 42:63-70. 
Ferreira DF (2011) Sisvar: a computer statistical analysis system. Ciência \& Agrotecnologia, 35:1039-1042.

Lacerda JJJ, Resende ÁV, Neto AEF, Hickmann C \& Conceição OP (2015) Fertilization, grain yield and profitability of the rotation between soybean and corn in soil with improved fertility. Pesquisa Agropecuária Brasileira, 50:769-778.

Lana MDC, Rampim L, Ohland T \& Fávero F (2014) Spacing, population density and nitrogen fertilization in corn grown in an Oxisoil. Revista Ceres, 61:424-433.

Miotto Júnior E (2014) Desenvolvimento e produtividade da cultura do milho sob densidades de plantas e espaçamentos entre linhas simples e duplas. Dissertação de Mestrado. Universidade Tecnológica Federal do Paraná, Pato Branco. 65p.

Novacek MJ, Mason SC, Galusha TD \& Yaseen M (2013) Twin rows minimally impact irrigated maize yield, morphology, and lodging. Agronomy Journal, 105:268-276.

Raij BV, Andrade JC, Cantarella H \& Quaggio JA (2001) Análise química para avaliação da fertilidade de solos tropicais. Campinas, Instituto Agronômico. 285p.

Robles M, Ciampitti IA \& Yyn TJ (2012) Responses of maize hybrids to twin-row spatial arrangement at multiple plant densities. Agronomy Journal, 104:1747-1756.
Thomas E \& Mahanna B (2018) Corn populations and row width deserve review. Hoarde's Dairyman - Crops \& Forages. Iowa: v. 344, p.4,. Available at: 〈http://www.hoards.com/E_crops/cf30〉. Accessed on: June $4^{\text {th }}, 2018$.

Uribe RAM, Kolln OT \& Gava GJC (2017) Evaluación de la densidad de plantas, componentes fenológicos de producción y rendimiento de granos en diferentes materiales genéticos de maíz. Idesia, 35:23-30.

USDA - United States Department Agriculture (2018) Statistics of grain and feed. Available at: <https://www.nass.usda.gov/ Publications/Ag_Statistics/2017/Chapter01.pdf > Accessed on: December $11^{\text {th }}, 2018$

Vanlauwe B, Kihara J, Chivenge P, Pypers P, Coe R \& Six J (2011) Agronomic use efficiency of $\mathrm{N}$ fertilizer in maize-based systems in sub-Saharan Africa within the context of integrated soil fertility management. Plant and Soil, 339:35-50.

Yan P, Pan J, Zhang W, Shi J, Chen X \& Cui Z (2017) A high plant density reduces the ability of maize to use soil nitrogen. PLOS one, 12:1-12. 